\title{
杂草稻的特性及其危害与防治研究进展
}

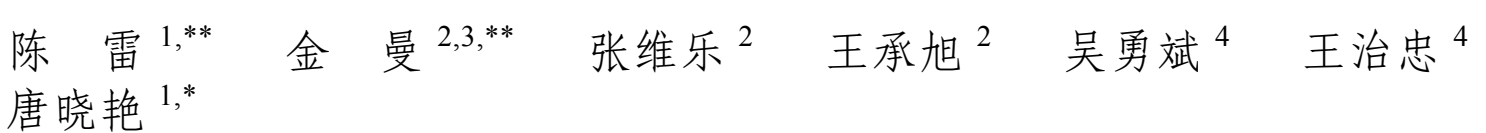

\footnotetext{
${ }^{1}$ 华南师范大学生命科学学院, 广东广州 $510631 ;^{2}$ 深圳市作物分子设计育种研究院, 广东深圳 $518110 ;{ }^{3}$ 华南农业大学生命科学学 院, 广东广州 $510642 ;{ }^{4}$ 仲衍种业股份有限公司, 四川成都 610000
}

摘 要: 杂草稻(Oryza sativa f. spontanea)泛指具有杂草特性的水稻, 是稻田中的恶性杂草之一, 在生产中可严重危 害栽培稻的产量和品质。本文从杂草稻的形态特性、落粒性、休眠性、耐逆性等方面概述其生物学特征。简要阐述 了杂草稻起源于栽培稻的去驯化过程, 分布范围涵盖世界稻作生产区, 在我国杂草稻的发生分布不均, 以江苏中南 部以及广东的湛江等地最为严重。进一步分析了由于杂草稻导致对稻米产量、稻米品质以及稻田生态环境造成的影 响和危害, 并提出了杂草稻的综合防控与治理措施, 包括预防控制、合理耕作、科学使用化学除草剂等方式, 以便有 效地控制杂草稻的发生与传播。

关键词: 杂草稻; 生物学特性; 危害; 防治措施

\section{Research advances on characteristics, damage and control measures of weedy rice}

CHEN Lei ${ }^{1, * *}, J_{N} M^{2,3,{ }^{* *}}$, ZHANG Wei-Le ${ }^{2}$, WANG Cheng-Xu' ${ }^{2}$, WU Yong-Bin ${ }^{4}$, WANG Zhi-Zhong ${ }^{4}$, and TANG Xiao-Yan ${ }^{1, *}$

${ }^{1}$ College of Life Science, South China Normal University, Guangzhou 510631, Guangdong, China; ${ }^{2}$ Shenzhen Institute of Molecular Crop Design, Shenzhen 518110, Guangdong, China; ${ }^{3}$ College of Life Science, South China Agricultural University, Guangzhou 510631, Guangdong, China;

${ }^{4}$ Zoeve Seed Co, Ltd, Chengdu 610000, Sichuan, China

\begin{abstract}
Weedy rice (Oryza sativa f. spontanea) presumably originated from rice but has weedy characteristics. It is one of the malignant weeds in rice field that decreases rice production and grain quality severely. In this study, the biological characteristics of weedy rice were described from morphology, shattering, dormancy and stress tolerance. The process of weedy rice origination from de-domestication of cultivated rice was summarized briefly. We also introduced the worldwide distribution of weedy rice as well as its non-uniform distribution in China with the most severe occurrence in middle-south area of Jiangsu province and Zhanjiang of Guangzhou province. In addition, we analyzed the agricultural damage on rice yield, rice quality and paddy field ecology environment by weedy rice. To control the occurrence and spread of weedy rice, we further proposed comprehensive measures, including prevention and controlling measures, reasonable cultivation system, and scientific use of chemical herbicides.
\end{abstract}

Keywords: weedy rice; biological characteristics; damage; prevention and control measures

杂草稻是一类在植株性状和生长形态方面与栽 培稻相似, 但是其稻米质量品质和结实率等方面却 不符合栽培稻生产实际需求的杂草 ${ }^{[1]}$ 。杂草稻是稻 田中除稗草和千金子以外的第三大恶性杂草, 具有
早熟、易落粒、休眠性强和繁殖系数高等特性。在 全世界的各水稻种植区，杂草稻均有不同程度的发 生。近年来, 由于我国水稻直播面积的逐年扩大、 水稻轻减化栽培的推广以及机械水平的提高, 导致

\footnotetext{
本研究由中国博士后基金(2019M652920, 2018M633069)和国家自然科学基金项目(31901532)资助。

The study was supported by the China Postdoctoral Science Foundation (2019M652920, 2018M633069) and the National Natural Science Foundation of China (31901532).

* 通信作者(Corresponding author): 唐晓艳, E-mail: txy@frontier-ag.com

** 同等贡献(Contributed equally to this work)

Received (收稿日期): 2019-11-07; Accepted (接受日期): 2020-03-18; Published online (网络出版日期): 2020-04-16.

URL: http://kns.cnki.net/kcms/detail/11.1809.S.20200416.1442.004.html
} 
杂草稻的发生日益频繁、范围逐渐扩大, 严重影响水 稻的产量和品质, 对我国的粮食生产与粮食安全造 成严重危害 ${ }^{[2]}$ 。因此, 对杂草稻的生物学特征, 起源、 分布与传播, 及其危害进行汇总分析, 有助于研究者 对杂草稻进行系统认知, 为栽培稻的种质改良以及 杂草稻的全面综合有效的防治提供详实的理论依据。

\section{1 杂草稻}

\section{1 杂草稻的生物学特征}

\subsection{1 形态特征苗期, 杂草稻出苗快、叶色淡、} 植株高大, 株型松散, 叶片长而宽且多线毛, 叶舌 和叶耳多为红褐色 ${ }^{[3]}$ 。分菜期, 杂草稻较栽培稻株高 更高、分萻更多, 并且具有更强的光合竞争能力, 生 长优势明显 ${ }^{[4]}$ 。生殖生长期, 杂草稻的柱头外露率可 高达 $30 \% \sim 40 \%$, 并且异交结实率高, 因此在田间杂 草稻的变异类型较多 ${ }^{[5]}$ 。成熟期, 部分杂草稻的颖 壳、芒以及种皮等部位呈现出红色或棕色, 可以很 容易地将其与栽培稻区分开来 ${ }^{[6]}$ 。图 1 拍摄于深圳 市光明区的水稻试验田。

\subsection{2 落粒性据研究报道, 在开花后 $9 \mathrm{~d}$ 杂草} 稻便开始落粒, 在开花后 $30 \mathrm{~d}$ 杂草稻落粒率可达 $65 \%{ }^{[5]}$ 。研究人员对杂草稻落粒性基因的定位及其 分子机制已开展了较为深入的研究, $\mathrm{Gu}$ 等 ${ }^{[7]}$ 以杂草 稻 SS18-2 和栽培稻 EM93-1 构建群体, 将杂草稻的
落粒基因定位至 3 号、4 号、7号和 8 号染色体上; Bres-Party 等 ${ }^{[8]}$ 利用构建的 DH 群体将一个杂草稻的 落粒基因定位至 1 号染色体 RM212 附近; Thurber 等 ${ }^{[9]}$ 对控制杂草稻落粒性的一个显性基因 SH4 进行 了研究分析, 发现杂草稻在进化的过程中先与祖先 发生分离, 而后又通过选择遗传机制重新获得了易 落粒的性状。本实验室从广东湛江收集了籼型杂草 稻 WR1、从安徽滁州收集了籼型杂草稻 WR2、从浙 江湖州收集了粳型杂草稻 WR3, 种植于试验田中, 通过数显拉力计对处于同一成熟时期的栽培稻黄华 占(HHZ)以及 3 个来源的杂草稻(WR1, WR2, WR3) 的穗-粒分离力进行测定, 结果表明(图 2), 杂草稻的 穗-粒分离力远小于栽培稻。

1.1 .3 休眠性与栽培稻相比, 杂草稻种子具有 一定的休眠性与较长的种子活性期 ${ }^{[10]}$ 。将杂草稻和 栽培稻的种子埋在土壤中, 每年定期检测两种水稻 种子的发芽率。实验发现, 杂草稻的种子在 5 年后 仍保持着 $12 \%$ 25\%的发芽率，而栽培稻的种子在第 一年就失去了萌发的能力 ${ }^{[11]}$ 。 $\mathrm{Gu}$ 等 ${ }^{[7]}$ 对杂草稻进行 了 QTL 定位, 将杂草稻的休眠基因定位至 4 号、6 号、7 号、8 号和 12 号染色体上。进一步的研究表 明, 定位在 12 号染色体上的 $q S D 12$ 基因可能在杂草 稻种子发育早期起关键作用, 可以通过促进体内 ABA 的积累而引起种子休眠 ${ }^{[12]}$ 。
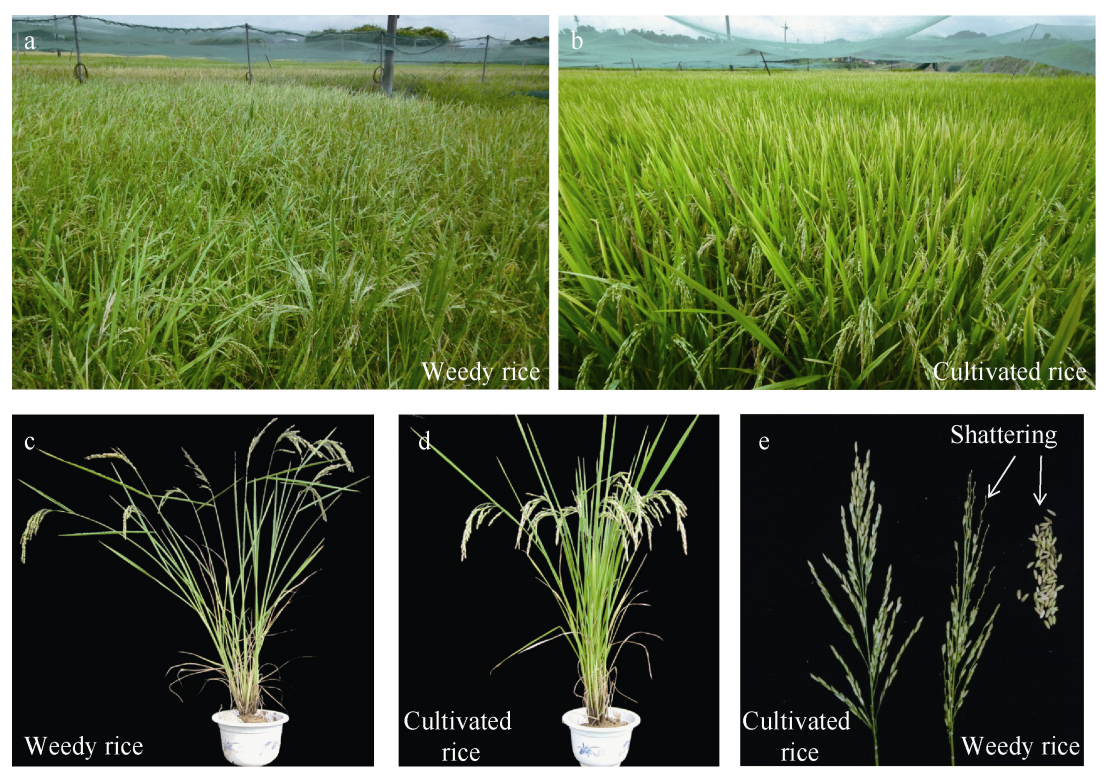

图 1 杂草稻与栽培稻的形态特征比较

Fig. 1 Comparison of morphological characteristics of weedy rice and cultivated rice

a: 田间杂草稻; b: 田间栽培稻; c: 杂草稻单株; d: 栽培稻单株; e: 栽培稻与杂草稻落粒性。

a: weedy rice in field; b: cultivated rice in field; c: single plant of weedy rice; d: single plant of cultivated rice; e: the trait of seed shattering between weedy rice and cultivated rice. 


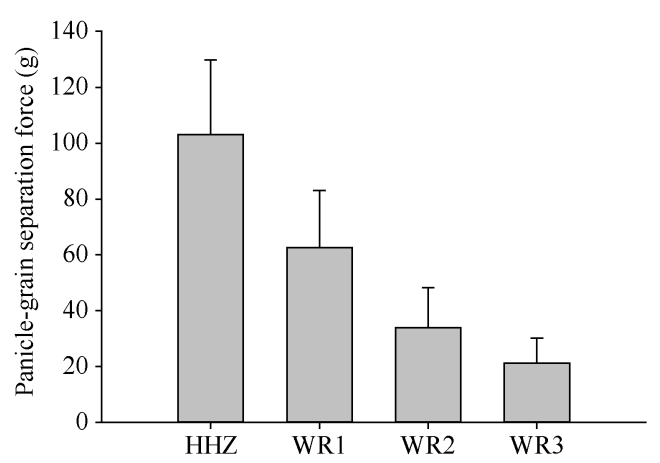

图 2 栽培稻与杂草稻穗-粒分离力测定

Fig. 2 Determination of panicle-grain separation force for cultivated rice and weedy rice

HHZ: 栽培稻黄华占; WR 1: 杂草稻 1; WR2: 杂草稻 2; WR 3: 杂 草稻 3 。通过数显拉力计对栽培稻与杂草稻的穗-粒分离力 $(\mathrm{g})$ 进 行测定, 每株测定 3 穗, 每穗至少测定 20 粒种子。

HHZ: cultivated rice Huanghuazhan; WR1: weedy rice 1; WR2: weedy rice 2; WR3: weedy rice 3. Panicle-grain separation force (g) of cultivated and weedy rice was measured with a digital tensile force meter using three panicles per plant and at least 20 seeds per panicle.

\subsection{4 而逆性 由于杂草稻生长的环境条件比} 较恶劣, 在长期的演化过程中杂草稻具备了耐寒
性、耐旱性以及耐盐性等许多性状。杂草稻种子的 萌发试验表明, 杂草稻和栽培稻在耐低温发芽和耐 干旱、耐盐等方面存在着显著的差异。杂草稻比栽 培稻更耐低温, 且在低温条件下的发芽率更高 ${ }^{[13]}$ 。 在人为模拟干旱处理的条件下, 与栽培稻相比, 大 多数的杂草稻在苗期就表现出较强的耐旱能力, 少 数表现出极强的耐旱能力 ${ }^{[14-15]}$ 。对杂草稻耐盐性的 研究表明, 经过不同浓度 $\mathrm{NaCl}$ 溶液处理后的杂草 稻的种子, 其发芽率、发芽势以及芽的伸长受盐胁 迫影响均较小, 杂草稻的种子最高可耐受 $0.5 \%$ 的 盐浓度 ${ }^{[16-17]}$ 。

\section{2 杂草稻的起源、分布与传播}

1.2.1 杂草稻的起源 大量的研究表明杂草稻起 源于栽培稻的去驯化过程。研究者对 238 份杂草稻 和栽培稻进行全基因组重测序, 通过进化树分析发 现，所有的杂草稻均可以和栽培稻聚类在一起，而 大多数聚类在一起的栽培稻和杂草稻来源于同一区 域(图 3-a); 主成分分析结果也表明不同地区的杂草 稻可以和当地的栽培稻聚类成簇(图 3-b $)^{[18]}$ 。这表明,
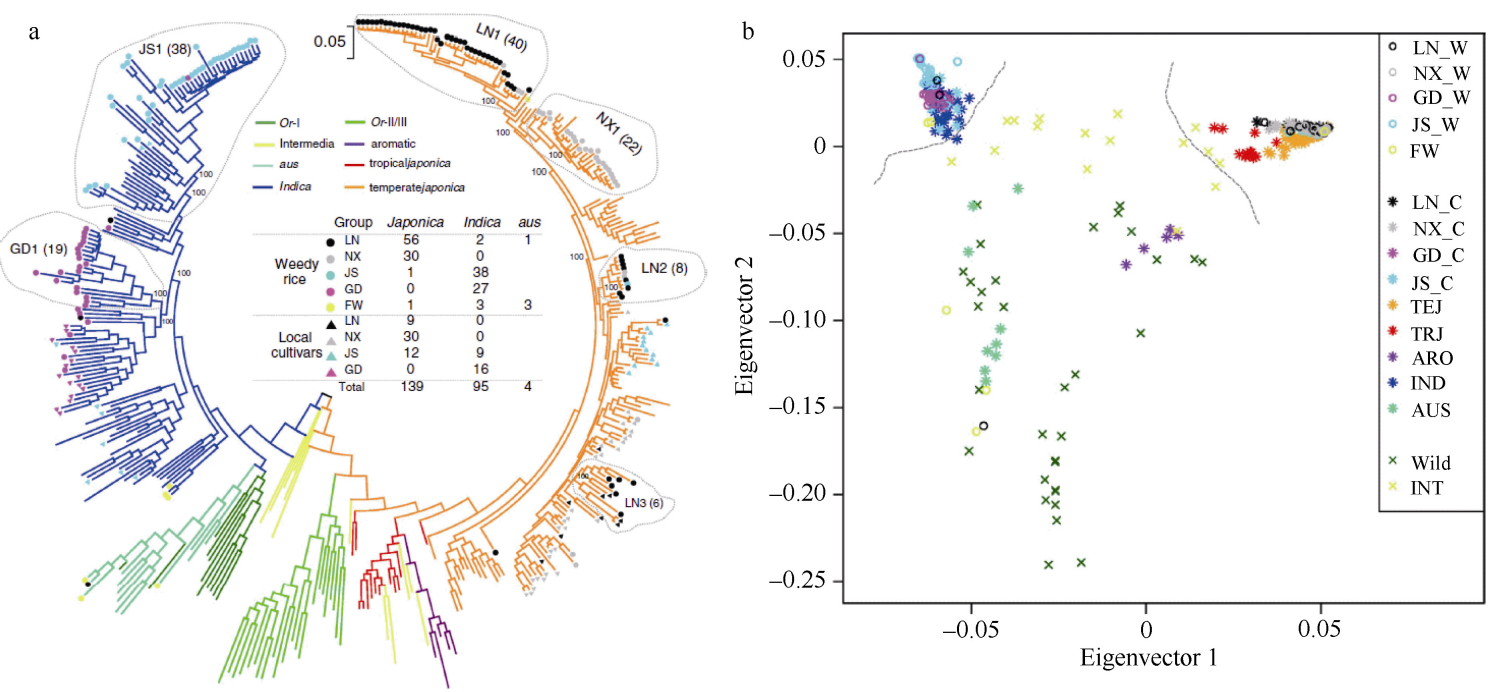

图 3 基于全基因组 SNPs 的杂草稻种群结构分析 ${ }^{[18]}$

Fig. 3 Population structure analysis of weedy rice based on genome-wide SNP ${ }^{[18]}$

a: 杂草稻、栽培稻以及其他品种水稻的进化树分析。不同的颜色表示不同的水稻品种: O. rufipogon: 绿色表示 Or-II 和 Or-III亚群，深 绿色表示 Or-I 亚群; aus: 淡绿色; O. sativa ssp. japonica: 紫色表示 Aromatic japonica (ARO), 红色表示 Tropical japonica (TRJ), 橘 红色表示 Temperate japonica (TEJ); O. sativa ssp. indica (IND): 蓝色; 中间型: 黄色。在进化树中, 圆点表示杂草稻, 三角表示栽培稻, LN 代表辽宁, NX 代表宁夏, JS 代表江苏, GD 代表广东, FW 代表中国地区以外的杂草稻品种。b: 杂草稻、栽培稻以及其他品种水稻 的主成分分析(PCA)。“o”表示杂草稻, “X”表示栽培稻, “*”表示中间型品种。标注中, 后缀“W”指杂草稻, “C”指本地栽培稻。2 条灰色 的虚线用于区分籼稻、粳稻和其他水稻品种。

a: A maximum-likelihood phylogenetic tree of weedy rice, cultivated rice and other Oryza varieties. Different subgroups are coded with different colours. O. rufipogon: green for the Or-II and Or-III subgroups, dark green for the Or-I subgroup; aus: light green; O. sativa ssp. japonica: purple for Aromatic japonica (ARO), red for Tropical japonica (TRJ); orange for Temperate japonica (TEJ); blue for O. sativa ssp. indica (IND); yellow for intermediate type. Dots and triangles indicate the weedy rice and cultivated rice, respectively, among them LN for Liaoning, NX for Ningxia, JS for Jiangsu, GD for Guangdong, and FW for weedy rice sampled outside of China, in the phylogenetic tree. b: Principal component analysis (PCA) of weedy rice, cultivated rice and other Oryza species by the first and second eigenvectors. All weedy rice are marked by ' $\mathrm{o}$ ', cultivated rice by ' $\mathrm{X}$ ', while wild-/intermediate-type rice by '*'. In the legend, the suffix ' $\mathrm{W}$ ' referred to weedy rice, and ' $\mathrm{C}$ ' for local cultivated rice. Two grey lines were used to distinguish indica and japonica subspecies from others. 
杂草稻并非直接来源于野生水稻品种, 也并不是简 单地将栽培稻的基因直接恢复为野生型, 而是由多 个独立的去驯化事件产生，通过自身的基因变异与 当地栽培稻基因的渗入, 并利用新的分子机制去适 应环境 ${ }^{[18]}$ 。此外, 我国南部地区杂草稻的全基因组测 序结果也表明杂草稻起源于籼稻与粳稻的杂交后代, 在杂草稻中检测发现新固定的单核甘酸多态性可能 由籼粳杂交后产生, 用于适应环境变化 ${ }^{[19]}$ 。对美国的 杂草稻进行基因组测序, 结果分析表明南亚栽培稻 祖先的去驯化过程是美国杂草稻形成的主要原因 ${ }^{[20]}$ 。 1.2 .2 杂草稻的分布杂草稻广泛分布于全球 50 多个国家, 几乎全世界所有的稻作生产地均有杂 草稻的发生, 例如美洲的美国、巴西; 欧洲的意大 利、希腊; 亚洲的中国、日本、印度; 大洋洲的澳大 利亚等国。

在中国，水稻种植面积达 2800 万公顷，其中受 杂草稻影响的面积超过 300 万公顷 ${ }^{[21]}$ 。杂草稻发生 危害最为严重的地区是江苏的中南部以及广东的湛 江等地。据报道，江苏省水稻种植区杂草稻的发生 面积已达 20 万公顷, 约占水稻直播稻总面积的四分 之一。受杂草稻影响而导致水稻平均减产约为 $20 \%$, 严重的可达 60\% $80 \%$, 甚至绝收 ${ }^{[22]}$ 。在扬州和泰州 的杂草稻田研究发现, 上一年杂草稻发生多的田块, 如果不采取有效的措施, 当年杂草稻的危害可达 $28 \%$ 以上, 严重的甚至达 $99 \%$ 以上 ${ }^{[10]}$ 。广东省湛江 雷州、惠州惠东以及肇庆封开地区杂草稻的发生也 较为严重。湛江雷州地区杂草稻发生量基本上在 18.1 株 $\mathrm{m}^{-2}$ 以上, 惠州惠东地区杂草稻发生量为 2.3 株 $\mathrm{m}^{-2}$, 肇庆封开县杂草稻数量在 1.6 株 $\mathrm{m}^{-2}$ 以上, 综合危害值基本达到 $29 \%$, 这给当地的水稻生产带 来严重影响 ${ }^{[23]}$ 。

\subsection{3 杂草稻的传播杂草稻的传播主要有以下} 几种途径: 一是随稻种传播。由于在稻种中混杂大 量杂草稻种子或繁种田原本含有杂草稻, 且在种子 生产中去杂不全, 调运过程检验不严等原因, 导致 杂草稻的种子随着稻种的调运而传播 ${ }^{[24]}$ 。二是在农 事操作中通过机械流动作业传播。随着水稻机械化 水平的提高, 机械收割越来越普遍, 跨区域的水稻 收割很容易就将杂草稻的种子携带到其他地区。三 是通过灌溉等过程造成杂草稻近距离扩散, 散落的 杂草稻种子随灌溉的水流外侵稻田, 扩散蔓延 ${ }^{[25]}$ 。 此外, 由于水稻轻简化栽培技术的迅速推广, 直播、 少耕、免耕等栽培方式的运用为土壤表面残存的杂
草稻种子提供了适宜的生长环境, 导致杂草稻的发 生愈演愈烈。

\section{2 杂草稻的危害}

杂草稻在稻田中的危害仅次于稗草和千金子, 是严重威胁水稻生产的第三大恶性杂草 ${ }^{[26]}$ 。水稻轻 简化栽培技术的推广以及农业机械化水平的提高, 加剧了杂草稻的发生、扩散与传播, 对水稻的产量、 品质以及生态环境造成严重危害。

\section{1 对稻米产量的影响}

在稻田中, 杂草稻会与栽培稻竞争一系列的生 长资源, 如阳光、水分、养分以及生长空间。这种 竞争贯穿于栽培稻的整个生长周期, 导致栽培稻产 量和品质的下降。首先, 相比于栽培稻杂草稻具有 植株高、叶片大、分菜数多等特征, 这些特性使得 杂草稻可以占据很较多的空间，从而相对栽培稻表 现出巨大的竞争优势 ${ }^{[27]}$ 。其次, 与栽培稻相比, 杂草 稻对氮素的利用效率更高, 生长速度和生物量积累 的速度比栽培稻更快, 从而导致杂草稻的成熟早于 栽培稻 ${ }^{[28]}$ 。此外, 杂草稻在与栽培稻竞争性地生长 过程中, 会减弱栽培稻根系的氧化能力、减少根系 的吸收面积、加剧根冠化等, 从而抑制栽培稻根系 的生理机能和生长发育 ${ }^{[29]}$ 。随着田间杂草稻密度的 增加, 抑制程度更加显著。最终, 栽培稻地上部分的 生长受到抑制, 导致栽培稻的产量显著减少 ${ }^{[30]}$ 。

研究发现, 当杂草稻发生的密度为 6 株 $\mathrm{m}^{-2}$, 栽培稻的产量减少 $20 \%$; 当杂草稻密度为 30 株 $\mathrm{m}^{-2}$, 栽培稻的产量减少 $50 \%$; 当杂草稻密度为 80 株 $\mathrm{m}^{-2}$, 栽培稻的产量减少可达 $90 \%$ 以上 ${ }^{[31]}$ 。以广东省雷州 市的水稻直播田为例, 雷州市植保站的调查结果表 明: 2009 年, 全市受杂草稻影响的稻田面积为 1.54 万公顷，占当年水稻种植总面积的 $24.2 \% ; 2010$ 年, 全市受杂草稻影响的稻田面积为 1.86 万公顷, 占当 年水稻种植总面积的 $29.5 \%$ 。在正常情况下, 雷州市 的水稻单季产量约为 $6375 \sim 7875 \mathrm{~kg} \mathrm{hm}^{-2}$, 但是, 当 杂草稻的发生率为 $5.8 \%$ 时, 水稻产量降至 $5784 \mathrm{~kg}$ $\mathrm{hm}^{-2}$; 当杂草稻的发生率为 $7.9 \%$ 时, 水稻产量降至 $5677 \mathrm{~kg} \mathrm{hm}^{-2}$; 当杂草稻发生率为 $31.9 \%$ 时，水稻产 量降至 $3223 \mathrm{~kg} \mathrm{hm}^{-2}$ 。雷州半岛水稻直播区域的产量 受到杂草稻的危害十分严重 ${ }^{[32]}$ 。

\section{2 对稻米品质的影响}

杂草稻早熟, 易落粒, 可与栽培稻一起收割。杂 草稻的种皮多为棕红色、红褐色或紫红色, 具有不 同程度的色素沉淀。当栽培稻中混有杂草稻时, 不 
仅污染栽培稻的种质资源，而且严重影响稻米的外 观品质和商品价值 ${ }^{[33]}$ 。在稻米中混有杂草稻时, 需 要在加工过程中进行强研磨或色选, 以去除杂草稻 粒, 这会导致碎米率增加或出米率降低(图 4)。因此 在稻谷的收购过程中, 一旦发现含有杂草稻时, 加 工企业一般会拒收或者降低等级收购, 这大大降低 了稻米的收购价格，对农民造成一定的经济损失。 此外, 由于杂草稻种子具有较高的直链淀粉含量, 米粒硬度大而黏性小, 稻米中混有杂草稻种子会导 致大米食味品质变差 ${ }^{[34]}$ 。

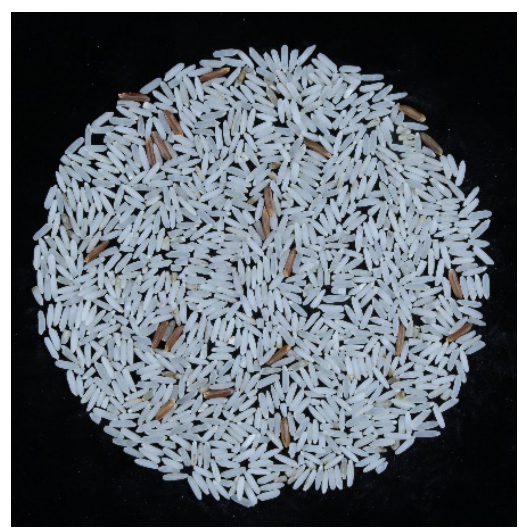

图 4 稻米中混杂杂草稻

Fig. 4 Weedy rice grains mixed with cultivated rice grains 图中白色的为栽培稻米粒, 红褐色的为杂草稻米粒。

The white grains are from cultivated rice, and the reddish-brown grains are from weedy rice.

\section{3 对生态的影响}

杂草稻可以与邻近的栽培稻之间发生基因漂移, 栽培稻中的优势基因漂移到杂草稻群体后可增强杂 草稻在稻田环境中的适应性。这些增强杂草稻适应 性的优势基因更容易在杂草稻的群体内固定下来, 在水稻田间造成持续的入侵危害。此外, 杂草稻本 身在阳光、水分、养分以及空间等生长资源方面具 有很强的竞争优势, 使得栽培稻的生长受到更为严 重的危害 ${ }^{[35]}$ 。

\section{3 杂草稻的防治策略}

杂草稻的入侵不仅严重影响栽培稻的产量和品 质, 而且对生态环境也造成一定的危害。因此, 迫切 需要通过采取预防控制措施、优化栽培技术、合理 使用除草剂以及引入抗除草剂的水稻新品种, 从而 有效地控制杂草稻的恶性传播、减少杂草稻带来的 危害。

\section{1 预防控制}

通过种源控制, 严格控制栽培稻原种的纯度,
确保其中没有混入杂草稻，从源头预防控制杂草稻 的入侵与传播 ${ }^{[36]}$ 。同时杜绝使用来自杂草稻发生严 重地区的种子, 以防止杂草稻向尚未发生的直播稻 作区的蔓延。除了种子污染外，杂草稻也可以通过 农事操作过程进行传播, 如机械收割导致的杂草稻 种子掉落田间, 以及灌溉造成的近距离杂草稻的传 播等 ${ }^{[33]}$ 。因此，为了预防控制杂草稻的入侵传播，在 采用高纯度的栽培稻种子的同时, 严格清理各种农 用机械, 杜绝杂草稻污染稻田。

\section{2 合理耕作}

3.2 .1 调整播种及栽培管理方式调整水稻播种 方式, 由直播栽培的方式改为移植栽培, 可以一定 程度上缓解杂草稻发生的危害。由于插秧时, 移栽 稻生长期提前, 移栽后生长迅速很快封行, 对刚刚 萌发出土的杂草稻种子会产生抑制作用。即使有一 小部分杂草稻发育成苗，由于其生长发育滞后于移 栽的栽培稻, 当杂草稻还仍未抽穗时栽培稻早已成 熟收获, 这就使得杂草稻难以散落和传播 ${ }^{[37]}$ 。

采用适宜的水分管理措施，在播种前对土壤进 行灌水处理, 通过建立水层降低杂草稻种子的萌发 出苗率 ${ }^{[38]}$ 。试验表明, 江西萍乡市杂草稻发生的田 里, 在冬春季采取连续 $70 \mathrm{~d}$ 保持饱和水层的措施, 可以显著降低杂草稻种子的萌发率 ${ }^{[39]}$ 。

在种植作物之前翻耕土壤，可以有效地抑制土 壤中残留的杂草稻种子发芽出苗, 从而减少杂草稻 种子在田间的入侵与扩散。收获上一季作物后, 对 田间土壤进行深旋耕或间隙深耕, 耕翻深度超过 $15 \mathrm{~cm}$, 确保将土壤表层的杂草稻种子埋到土壤下 层, 使其难以萌发出苗 ${ }^{[40]}$ 。

\section{2 .2 人工除草人工拔除田间的杂草稻是最} 直接, 也是最为原始的治理方式 ${ }^{[37]}$ 。在水稻三叶期 时, 通过杂草稻幼苗的形态特征可以与常规稻加以 区别, 具体表现为杂草稻植株高、叶片长、叶色浅, 长势好于栽培稻积苗等特征。此时应该及时对杂草 稻进行人工拔除，从而降低杂草稻的危害 ${ }^{[2]}$ 。虽然 人工除草在一定程度上减轻了杂草稻发生的危害, 但是大大增加了劳动力的投入，从而提高了水稻生 产成本。

3.2.3 轮作方式采用合理的轮作方式, 特别是 水旱轮作, 可以有效的防止杂草稻的发生 ${ }^{[38]}$ 。在冬季 种植蔬菜或其他旱地作物, 可有效阻止杂草稻的繁 殖, 并逐步减少杂草稻种子在土壤中的残留 ${ }^{[37]}$ 。此外, 水稻可以与高粱、大豆以及玉米等旱地作物轮作, 并 
结合使用选择性化学除草剂, 可以显著降低杂草稻 的发生和危害。研究表明, 采用水稻与大豆轮作的方 式，同时在大豆田中合理使用禾本科杂草的除草剂， 可以显著减轻杂草稻的发生和危害 ${ }^{[41]}$ 。

\section{3 化学除草}

化学除草是指合理采用化学除草剂对农田中的 杂草进行防治和管理 ${ }^{[26]}$ 。有研究报道利用浸种剂对 水稻种子浸种催芽, 播后 $2 \mathrm{~d}$ 喷施丙草胺对田间杂 草稻有一定的防治效果 ${ }^{[42]}$ 。但是, 由于杂草稻与栽 培稻在生理生化特性上十分相似, 因此按照常规方 法使用稻田除草剂, 很难做到灭杀杂草稻而不损害 秧苗的正常生长 ${ }^{[37]}$ 。因此, 化学除草也只能减少杂 草稻的发生, 降低杂草稻带来的危害, 但并不能从 根本上解决杂草稻的问题。
目前, 通过种植抗除草剂的水稻新品种, 并选 择性地使用相应的化学除草剂, 从而达到杀灭杂草 稻而对栽培稻没有损伤的目的, 以此降低杂草稻的 危害 ${ }^{[43]}$ 。近年来, 抗除草剂水稻的研究取得了重大 进展, 培育出一系列非转基因的抗除草剂水稻新品 种, 例如, 巴斯夫公司推出 Clearfield 水稻以及 Provisia 水稻系列均为非转基因耐除草剂水稻。在我 国, 深圳作物分子设计育种研究院和深圳兴旺生物 种业公司共同研发的洁田技术，利用非转基因抗除 草剂的水稻与其专用除草剂配合使用, 可以有效地 防治直播稻田中的杂草稻。广东省雷州市水稻的小 区试验表明，采用洁田技术可以有效地控制直播稻 田中杂草稻的数量。通过对田间杂草稻密度的高效控 制, 提高了水稻的产量, 增产增收效果显著(表 1$)^{[44]}$ 。

表 1 广东省雷州市洁田技术防控杂草稻试验结果 ${ }^{[4]}$

Table 1 The results of weedy rice control using Tidy Field in Leizhou, Guangdong province ${ }^{[44]}$

\begin{tabular}{|c|c|c|}
\hline $\begin{array}{l}\text { 性状 } \\
\text { Trait }\end{array}$ & $\begin{array}{l}\text { 洁田技术 } \\
\text { Tidy Field } \\
\end{array}$ & $\begin{array}{c}\text { 常规化学除草 } \\
\text { Conventional chemical weeding }\end{array}$ \\
\hline 杂草稻发生率 Occurrence rare of weedy rice (\%) & 0.07 & 13.31 \\
\hline 有效穗 Effective panicles (Ten thousands panicles per hectare) & 349.35 & 337.50 \\
\hline 每穗总粒数 Grain number per panicle & 120.43 & 123.20 \\
\hline 结实率 Seed-setting rate (\%) & 82.73 & 73.70 \\
\hline 千粒重 Thousand-grain weight (g) & 21.47 & 22.33 \\
\hline 理论产量 Theoretical yield $\left(\mathrm{kg} \mathrm{hm}^{-2}\right)$ & 7447.65 & 6847.20 \\
\hline 实际产量 Actual yield $\left(\mathrm{kg} \mathrm{hm}^{-2}\right)$ & 6366.30 & 5868.15 \\
\hline 比对照增产 Yield increase compared to control (\%) & & 8.54 \\
\hline
\end{tabular}

洁田技术是指在水稻三至五叶期, 每公顷用洁田稻专用除草剂(主要成分为甲咪唑烟酸) $600 \mathrm{~mL}$ 兑水 $450 \mathrm{~kg}$ 喷雾。常规化学除草是指 播种后 $1 \mathrm{~d}$, 每公顷用 $30 \%$ 丙草胺乳油 $1125 \mathrm{~mL}$ 兑水 $450 \mathrm{~kg}$ 喷雾, 播种后 $12 \mathrm{~d}$, 每公顷用 $35 \%$ 苄.二氯可湿性粉剂 $600 \mathrm{~g}$ 混合化肥撒施。 试验地分别选在杨家镇安榄洋、白沙镇东井洋、松竹镇刘宅洋。

Tidy Field refers to spray $600 \mathrm{~mL}$ Tidy Field herbicide with $450 \mathrm{~kg}$ water per hectare at rice 3-5 leaf stage; Conventional chemical weeding refers to spray $1125 \mathrm{~mL} 30 \%$ promethamine with $450 \mathrm{~kg}$ water per hectare one day after sowing, and 12 days after sowing apply $600 \mathrm{~g} 35 \%$ benzyl dichloride powder mixed with fertilizer. The experiment plots were located in Anlanyang in Yangjia Town, Dongjingyang in Baisha Town, and Liuzhaiyang in Songzhu Town.

随着生物技术的迅速发展, CRISPR/Cas9 基因 编辑技术已广泛应用于植物的基因编辑。通过对目 标基因的敲除、插入以及定点编辑, 从而达到改良 作物性状的目的, 为农作物分子育种设计提供了新 的思路。例如, 研究者利用非同源末端连接修复以 及 CRISPR/Cas9 技术, 对水稻内源 EPSPs 基因进行 定点突变, 从而获得了抗草甘膦的水稻材料 ${ }^{[45]}$ 。也 有研究者运用 CRISPR/Cas9 技术, 采用碱基替换和 碱基插入的策略定向改造水稻 ALS 基因, 获得了含 有不连续点突变的 ALS (acetolactate synthase)基因 的抗除草剂水稻材料 ${ }^{[46]}$ 。

\section{4 展望}

杂草稻作为严重危害水稻品质和产量的稻田恶 性杂草之一, 必须采用多种防治措施加以综合管理。 同时, 由于杂草稻具有丰富的遗传基础和变异类型, 具有耐寒性、耐旱性、耐盐性等广适优秀性状，可以 充分利用杂草稻的这些特异的稻属资源, 结合传统 育种以及分子育种手段, 丰富现有栽培稻品种的遗 传基础, 培育出具有优良抗性的水稻品种。

\section{References}

[1] 吴文革, 季雅岗, 习敏, 许有尊, 孙雪原. 杂草稻的生物学特 
性及利用研究进展. 安徽农业科学, 2018, 46(17): 30-33. Wu W G, Ji Y F, Xi M, Xu Y Z, Sun X Y. Research progress on biological characteristics of weedy rice and its utilization. J Anhui Agric Sci, 2018, 46(17): 30-33 (in Chinese with English abstract).

[2] 梁帝允, 强胜. 我国杂草稻危害现状及其防控对策. 中国植保 导刊, 2011, 31(3): 21-24.

Liang D Y, Qiang S. The present situation of weedy rice in China and its prevention and control measures. China Plant Prot, 2011, 31(3): 21-24 (in Chinese).

[3] 张峥, 戴伟民, 章超斌, 强胜. 江苏沿江地区杂草稻的生物学 特性及危害调查. 中国农业科学, 2012, 45: 2856-2866.

Zhang Z, Dai W M, Zhang C B, Qiang S. Investigation of the biological characteristics and harmfulness of weedy rice (Oryza sativa L. f. spontanea) occurred in the regions along the Yangtze River of Jiangsu province. Sci Agric Sin, 2012, 45: 2856-2866 (in Chinese with English abstract).

[4] 刘冠明, 林青山, 江奕君, 陈青春, 徐庆国. 杂草稻研究进展. 中国农学通报, 2014, 30(21): 9-13.

Liu G M, Lin Q S, Jiang Y J, Chen Q C, Xu Q G. The research advances on weedy rice. Chin Agric Sci Bull, 2014, 30(21): 9-13 (in Chinese with English abstract).

[5] 杨巍, 吴其偯, 陈惠哲, 朱德峰. 杂草稻生物学特性、危害与 防治方法. 中国稻米, 2008, (3): 50-53.

Yang W, Wu Q B, Chen H Z, Zhu D F. Biological characteristics, hazards and control methods of weedy rice. China Rice, 2008, (3): 50-53 (in Chinese).

[6] 廖冬如, 曹端荣, 王修慧, 李浩元, 阮萍. 鄱阳湖区杂草稻生 物学特性研究初报. 江西植保, 2011, 34(1): 42-43.

Liao D R, Cao D R, Wang X H, Li H Y, Ruan P. Report on biological characteristics of weed rice in Poyang Lake Area. Jiangxi Plant Prot, 2011, 34(1): 42-43 (in Chinese).

[7] Gu X Y, Foley M E, Horvath D P, Anderson J V, Feng J H, Zhang L H, Mowry C R, Ye H, Suttle J C, Kadowaki K, Chen Z X. Association between seed dormancy and pericarp color is controlled by a pleiotropic gene that regulates abscisic acid and flavonoid synthesis in weedy red rice. Genetics, 2011, 189: 1515-1524.

[8] Bres-Patry C, Lorieux M, Clément G. Heredity and genetic mapping of domestication-related traits in a temperate japonica weedy rice. Theor Appl Genet, 2001, 102: 118-126.

[9] Thurber C S, Reagon M, Gross B L, Olsen K M, Jia Y, Caicedo A L. Molecular evolution of shattering loci in U.S. weedy rice. $\mathrm{Mol}$ Ecol, 2010, 19: 3271-3284.

[10] Guo X B, Ji H S, Feng C Y, Chen W M, Gu K L, Yuan Q. Study on damage characteristics of weedy rice. Agric Sci Tech, 2015, 16: 789-792.

[11] 马静, 孙建昌, 吴斌, 王兴盛. 宁夏杂草稻的生存传播习性研 究: III. 杂草稻种子的休眠性和存活能力. 种子, 2016, 35(9): 75-77.

Ma J, Sun J C, Wu B, Wang X S. Research of habits and characteristics about survival and spread of weedy rice in Ningxia: III. dormancy and biability of weedy rice seed. Seed, 2016, 35(9): $75-77$.

[12] Gu XY, Liu T, Feng J, Suttle JC, Gibbons J. The qSD12 underlying gene promotes abscisic acid accumulation in early developing seeds to induce primary dormancy in rice. Plant Mol Biol, 2010,
73: 97-104.

[13] 陈惠哲, 玄松南, 王渭霞, 邵国胜, 孙宗修. 丹东杂草稻种子 的耐冻能力和低温发芽特性研究. 中国水稻科学, 2004, 18: 109-112.

Chen H Z, Xuan S N, Wang W X, Shao G S, Sun Z X. Freezing tolerance and germination ability at low temperature of Dandong weedy rice. Chin J Rice Sci, 2004, 18: 109-112 (in Chinese with English abstract).

[14] 丁国华, 马殿荣, 马巍, 张丽丽, 陈温福. 杂草稻幼苗期耐旱 性的初步篮选与评价. 北方水稻, 2010, 40(1): 11-14.

Ding G H, Ma D R, Ma W, Zhang L L, Chen W F. Primary screening and identifying for drought resistance of weedy rice during seeding stage. North Rice, 2010, 40(1): 11-14 (in Chinese with English abstract).

[15] 丁国华, 马殿荣, 刘晓亮, 孔德秀, 高齐, 杨光, 唐亮, 高明超, 徐正进, 陈温福. 中国北方杂草稻幼苗对干旱胁迫的生理响 应. 干旱地区农业研究, 2013, 31(6): 127-133.

Ding G H, Ma D R, Liu X L, Kong D X, Gao Q, Yang G, Tang L, Gao M C, Xu Z J, Chen W F. Physiological responses of weedy rice to drought stress at seedling stage. Agric Res Arid Areas, 2013, 31(6): 127-133 (in Chinese with English abstract).

[16] 余柳青, Mortimer A M, 玄松南, 陆永良, 周勇军. 杂草稻落粒 粳的抗逆境特性研究. 应用生态学报, 2005, 16: 717-720.

Yu L Q, Mortimer A M, Xuan S N, Lu Y L, Zhou Y J. Stress resistance of weedy rice Luolijing (Oryza sativa). Chin J Appl Ecol, 2005, 16: 717-720 (in Chinese with English abstract).

[17] 赵娜, 马殿荣, 陈温. 北方杂草稻发芽期耐盐性的初步评价. 中国稻米, 2007, (2): 20-24.

Zhao N, Ma D R, Chen W. Preliminary evaluation of salt tolerance of weedy rice in north China during germination. China Rice, 2007, (2): 20-24 (in Chinese).

[18] Qiu J, Zhou Y J, Mao L F, Ye C Y, Wang W D, Zhang J P, Yu Y, Fu F, Wang Y F, Qian F J, Qi T, Wu S L, Sultana M H, Cao Y N, Wang Y, Timko M P, Ge S, Fan L J, Lu Y L. Genomic variation associated with local adaptation of weedy rice during de-domestication. Nat Commun, 2017, 8: 15323.

[19] Qiu J, Zhu J W, Fu F, Ye C Y, Wang W D, Mao L F, Lin Z X, Chen L, Zhang H Q, Guo L B, Qiang S, Lu Y L, Fan L J. Genome re-sequencing suggested a weedy rice origin from domesticated indica-japonica hybridization: a case study from southern China. Planta, 2014, 240: 1353-1363.

[20] Li L F, Li Y L, Jia Y, Caicedo A L, Olsen K M. Signatures of adaptation in the weedy rice genome. Nat Genet, 2017, 49: 811-814.

[21] 韩冰, 马小定, 崔迪, 王艳杰, 曹桂兰, 韩龙植. 杂草稻与栽 培稻和野生稻的亲缘演化关系研究. 见: 2017 年中国作物学会 学术年会摘要集. 北京: 中国作物学会, 2017. pp 145-146.

Han B, Ma X D, Cui D, Wang Y J, Cao G L, Han L Z. Study on the genetic evolution of weedy rice, cultivated rice and wild rice. In: Abstracts Collections of 2017 Annual Conference of Crop Science Society of China. Beijing: Crop Science Society of China, 2017. pp 145-146 (in Chinese).

[22] 陈晓锋, 强胜, 杨金玲, 张帮华, 张峥, 宋小玲, 戴伟民. 江苏 省杂草稻的传播与籼粳分化研究. 中国水稻科学, 2015, 29: 82-90.

Chen X F, Qiang S, Yang J L, Zhang B H, Zhang Z, Song X L, 
Dai W M. Hierarchical clustering and indica-japonica classification: uncover mutual spread and indica-japonica differentiation for weedy rice in Jiangsu province. Chin J Rice Sci, 2015, 29: 82-90 (in Chinese with English abstract).

[23] 张栋梁, 沈雪峰, 陈勇. 广东省杂草稻分布情况及其形态特征 分析. 见: 第十二届全国杂草科学大会论文摘要集. 北京: 中 国植物保护学会杂草学分会, 2015. p 18.

Zhang D L, Sheng X F, Chen Y. Distribution and morphological characteristics of weedy rice in Guangdong province. In: Abstracts Collections of the 12th National Conference on Weed Science. Beijing: Weed Science Society of China CSPP, 2015. p 18 (in Chinese).

[24] 曹涤环. 杂草稻的自述. 农药市场信息, 2016, (9): 72-73. Cao D H. Narration of weedy rice. Pestcide Market News, 2016, (9): 72-73 (in Chinese).

[25] 徐世林, 陈德辉, 李群, 张鹏. 稻田杂草稻发生规律及控制技 术探讨. 耕作与栽培, 2006, (6): 16-17.

Xu S L, Chen D H, Li Q, Zhang P. Study on occurrence regularity and control technology of weedy rice in rice field. Tillage and Cultivation, 2006, (6): 16-17 (in Chinese).

[26] 王哲, 戎俊, 卢宝荣. 杂草稻的发生、危害与我国水稻生产面 临的挑战. 杂草科学, 2015, 33(1): 1-9.

Wang Z, Rong J, Lu B R. Occurrence and damage of weedy rice and its threats to rice production in China. Weed Sci, 2015, 33(1): 1-9 (in Chinese with English abstract).

[27] 刘睿, 强胜, 宋小玲, 陈世国, 戴伟民. 杂草稻苗期强竞争性 的生理机制. 植物保护学报, 2015, 42: 138-144.

Liu R, Qiang S, Song X L, Chen S G, Dai W M. Physiological mechanisms of strong competition of weedy rice at seedling stage. $J$ Plant Prot, 2015, 42: 138-144 (in Chinese with English abstract).

[28] 吴云艳. 杂草稻竞争对栽培稻氮素积累量、氮素利用率及产量 的影响. 江苏农业学报, 2018, 34: 241-244.

$\mathrm{Wu}$ Y Y. Effect of weedy rice competition on the nitrogen accumulation, nitrogen utilization eddiciency and yield of cultivated rice. J Jiangsu Agric Sci, 2018, 34: 241-244 (in Chinese with English abstract).

[29] 杨庆. 相互竞争对栽培稻和杂草稻形态特性的影响. 中国农 学通报, 2016, 32(12): 1-5.

Yang Q. Mutual competition affecting the morphological characteristics of cultivated rice and weedy rice. Chin Agric Sci Bull, 2016, 32(12): 1-5 (in Chinese with English abstract).

[30] 吴云艳, 马殿荣, 李金英, 马巍, 陈温福. 杂草稻竞争对栽培 稻根系形态生理特性及产量的影响. 华北农学报, 2010, 25(5): 150-154.

Wu Y Y, Ma D R, Li J Y, Ma W, Chen W F. Effect of weedy rice on root morphological and physiological characteristics and yield of cultivated rice. Acta Agric Boreali-Sin, 2010, 25(5): 150-154 (in Chinese with English abstract)

[31] Zhang Z, Dai W, Song X, Qiang S. A model of the relationship between weedy rice seed-bank dynamics and rice-crop infestation and damage in Jiangsu province, China. Pest Manag Sci, 2014, 70: 716-724.

[32] 李国君, 何卓先, 王革, 柯保宁, 罗彩莲, 卢宝荣. 广东雷州 杂草稻的发生与危害及其防治对策. 杂草科学, 2013, 31(1): $20-25$.
Li G J, He Z X, Wang G, Ke B N, Luo C L, Lu B R. Occurrence, damage and control strategies of weedy rice in Leizhou, Guangdong province. Weed Sci, 2013, 31(1): 20-25 (in Chinese with English abstract).

[33] 张彬. 丙草胺防治水直播稻田杂草稻(Oryza sativa f. spontanea) 技术的研究. 南京农业大学硕士学位论文, 江苏南京 2014.

Zhang B. Control Technology of Pretilachlor for Weedy Rice (Oryza sativa f. spontanea) in Water-seed Rice. MS Thesis of Nanjing Agricultural University, Nanjing, Jiangsu, China, 2014 (in Chinese with English abstract).

[34] 王蓓, 何雨, 吴荣, 沈亚芳, 王洋, 赵光武. 杂草稻生物学特 性、发生与防控研究进展. 浙江农林大学学报, 2019, 36: 1028-1036.

Wang B, He Y, Wu R, Shen Y F, Wang Y, Zhao G W. Research progress on biological characteristics, occurrence and control of Oryza sativa f. spontanea. J Zhejiang A\&F Univ, 2019, 36: 1028-1036 (in Chinese with English abstract).

[35] 姚南. 基于叶绿体基因组序列多态性的杂草稻起源以及杂草 稻的落粒性研究. 重庆大学博士学位论文, 重庆 2015.

Yao N. The Study of Origin of Weedy Rice Based on Chloroplast Genome Sequence Polymorphism and a Preliminary Research in Seed Shattering of Weedy Rice. PhD Dissertation of Chongqing University, Chongqing, China, 2015 (in Chinese with English abstract).

[36] 马瑞敏, 马秀娟, 高建玲. 控制杂草稻传播的技术要点. 种子 世界, 2013, (1): 35 .

Ma R M, Ma X J, Gao J L. Key techniques for controlling the spread of weedy rice. Seed World, 2013, (1): 35 (in Chinese).

[37] 陈雨生, 曹珠平. 粤西直播稻作区杂草稻的发生危害与防治 对策. 农业科技通讯, 2009, (10): 117-119.

Chen Y S, Cao Z P. Occurrence and control measures of weedy rice in direct seeding rice growing areas in Western Guangdong area. Bull Agric Sci Tech, 2009, (10): 117-119 (in Chinese).

[38] 李其勇, 朱从桦, 李星月, 郭展, 张鸿. 水稻田杂草稻的发生 与防控技术对策. 四川农业科技, 2017, (7): 36-38.

Li Q Y, Zhu C H, Li X Y, Guo Z, Zhang H. Occurrence and control of weedy rice in paddy fields. J Sichuan Agric Sci Tech, 2017, (7): 36-38 (in Chinese).

[39] 龚朝辉, 龚航莲. 萍乡市杂草稻的发生与危害. 杂草科学, 2014, 32(1): 54-56.

Gong $\mathrm{C} \mathrm{H}$, Gong H L. Occurrence and damage of weedy rice (Oryza sativa L. f. spontanea) in Pingxiang city. Weed Sci, 2014, 32(1): 54-56 (in Chinese with English abstract).

[40] 刘延刚, 李相奎, 刘德友, 张明红, 王传祥, 王秀梅. 稻田杂 草稻防控关键技术集成与推广应用. 农业科技通讯, 2017, (6): 239-241.

Liu Y G, Li X K, Liu D Y, Zhang M H, Wang C X, Wang X M. Integration and popularization of key technologies of weed rice control in rice field. Bull Agric Sci Tech, 2017, (6): 239-241 (in Chinese).

[41] 袁晓丹, 刘亮, 曹凤秋, 柳参奎, 吴明根. 杂草稻的研究现状 与展望. 中国野生植物资源, 2006, (3): 5-7.

Yuan X D, Liu L, Cao F Q, Liu S K, Wu M G. Prospect and present situation of weedy rice research. Chin Wild Plant Resour, 2006, (3): 5-7 (in Chinese with English abstract).

[42] 沈雪峰, 梁居林, 陈勇, 张栋梁, 安静, 肖学明, 徐铮. 广东省 
杂草稻防控技术初探. 杂草科学, 2013, 31(3): 53-55.

Shen X F, Liang J L, Chen Y, Zhang D L, An J, Xiao X M, Xu Z. Preliminary study on the prevention and control of weedy rice in Guangdong province. Weed Sci, 2013, 31(3): 53-55 (in Chinese with English abstract).

[43] Shivrain V K, Burgos N R, Anders M M, Rajguru S N, Moore J, Sales M A. Gene flow between Clearfield (TM) rice and red rice. Crop Prot, 2007, 26: 349-356.

[44] 李瑞民, 陈雷, 丁林彬, 庄德奥. 洁田技术防控杂草稻试验初 报. 中国农技推广, 2018, 34(1): 61-62.
Li R M, Chen L, Ding L B, Zhuang D A. Report on the control of weedy rice by Tidy Field. China Agric Technol Extension, 2018, 34(1): 61-62 (in Chinese).

[45] Li J, Meng X, Zong Y, Chen K, Zhang H, Liu J, Li J, Gao C. Gene replacements and insertions in rice by intron targeting using CRISPR-Cas9. Nat Plants, 2016, 2: 16139.

[46] Sun Y W, Zhang X, Wu C Y, He Y B, Ma Y Z, Hou H, Guo X P, Du W M, Zhao Y D, Xia L Q. Engineering herbicide-resistant rice plants through CRISPR/Cas9-mediated homologous recombination of acetolactate synthase. Mol Plant, 2016, 9: 628-631. 